\title{
Psychosociální aspekty rizikového chování sportujících dětí
}

\section{Psychosocial aspects of a risk behavior in sporting children}

\author{
Pavel Slepička, Jiří Mudrák
}

Fakulta tělesné výchovy a sportu, Univerzita Karlova v Praze

\begin{abstract}
Abstrakt:
$V$ této přehledové studii se zabýváme některými rizikovými faktory ve sportu dětí a mládeže. Na přikladech výzkumů zabývajicich se dopingem, násilím a fair play ukazujeme, jak mohou normy vrcholového sportu zdůrazňujici soutěžní výsledky, maximálni výkon a vitězstvi za každou cenu přispivat $k$ rizikovému chování sportujicich dětí a mládeže, jako je napřiklad zneuživáni dopingu, nepřiměřené agresivitě či porušování pravidel a zásad fair play. Toto rizikové chování pak nezůstává omezeno pouze na kontext sportu, ale může se prenášet $i$ do běžného života mimo sport.
\end{abstract}

\begin{abstract}
:
In present overview study, we focus on some possible risk factors in child and youth sport. In the overview of contemporary research focusing on doping, violence and fair play, we show how the norms of contemporary competitive sport emphasizing results, maximal performance and victory at all cost may support risk behavior in sporting children and youth, such as doping abuse, inappropriate aggression, or breaking rules and fair play. It seems that this risk behavior is not limited only to the context of sport but translates also in the life outside sport.
\end{abstract}

Klíčová slova: sport, děti, mládež, doping, agrese, fair play

Key words: sport, children, youth, doping, aggression, fair play

Studie vznikla s podporou výzkumného záměru VZ MŠMT ČR MSM 0021620864 a projektu PRVOUK P39.

\section{ÚVOD}

Sport dětí a mládeže představuje významný společenský jev s celou řadou pozitivních funkcí. Sportujícím dětem slouží jako zábava naplňující volný čas, je aktivitou poskytující možnost odreagování a psychického uvolnění, obohacuje prožitkovou sféru o intenzivní emocionální i estetické prožitky. Sportovní aktivita nabízí příležitost k navazování sociálních kontaktů a rozvoji sociálních dovedností. Poskytuje také řadu možností pro seberealizaci, přináší prožitky úspěchu i zklamání. Pro dosažení sportovních cílů je nezbytné vynaložení úsilí a překonávání překážek, což ovlivňuje osobnost sportujícího jedince a pomáhá dotvářet jeho hodnotovou orientaci.

Toto pozitivní působení sportu dětí a mládeže však bývá často překrýváno některými závažnými negativními jevy, které mají vazbu na celospolečenské prostředí. K těmto jevům, stále více se vyskytujícím i ve sportu dětí a mládeže, lze přiřadit především tendence k užívání podpůrných látek, projevy agrese a násilí či nedodržování pravidel - podvádění. Sport dětí a mládeže tak může představovat také sociální mikroklima umožňující takové formy chování, které lze označit za rizikové, a to jak z hlediska celospolečenského, tak z hlediska osobnostního rozvoje sportujících dětí. Ukazuje se při tom, že zejména výkonnostně orientovaný sport dětí a mládeže s často enormním tlakem na okamžitý úspěch a jeho ekonomické zhodnocení vytváří prostředí stimulující rozvoj uvedeného rizikového chování. Sportu a jeho sociálnímu prostředí se pak klade za vinu, že ve jménu úspěchu mnohdy toleruje projevy agrese a násilí, nedostatečně se vypořádává s tendencí užívat podpůrné prostředky či s podváděním a překračováním sportovních pravidel. Tím se vytváří nestejné podmínky pro sportující jednice 
a ztrácí se kredit sportu jako činnosti spojované s principy fair play, které byl přisuzován pozitivní formativní vliv na sportující děti a mládež.

Závažné jsou tyto skutečnosti zejména proto, že vzorce chování osvojené v dětství se přenášejí do dospělosti, a proto nelze očekávat, že chování, které jsme označili v uvedených souvislostech za rizikové, vymizí samo od sebe s postupným dospíváním či opuštěním prostředí sportu. Sportovní praxe nasvědčuje, že toto rizikové chování se často přenáší z oblasti sportu do běžného života a může se stát i trvalou součástí vzorců chování. Proto se v dalších částech stati budeme věnovat problematice užívání dopingu a rovněž se zaměříme na projevy násilí a porušování zásad fair play mezi sportující mládeží.

\section{Doping a sportující mládě̆}

Problematika užívání podpůrných látek ve sportu dětí a mládeže se stává stále závažnějším problémem, který přitahuje pozornost sociálněvědních i medicínských oborů. Ty se snaží tuto problematiku analyzovat jak z hlediska prŕíčin, tak z hlediska možných psychosociálních a zdravotních dopadů.

V českém kontextu je možné uvést množství výzkumů, které se této problematice věnovaly jak z hledisek psychosociálních, tak medicínských. Celá řada studií (např. Nekola, Chlumský, 1994; Slepička, Slepičková, 1996, 1997; Pyšný, 1999; Slepička, Slepičková, Pyšný, Ludviková, 1998; Slepička, Pyšný, 2000; Kabiček, 2005) přináší množství poznatků o příčinách zneužívání dopingu, jeho souvislostech s pronikáním komercionalizace do oblasti sportu dětí, o vlivech sociálního mikroklimatu, reprezentovaného zejména rodiči, trenéry či školou. Jsou v nich prezentovány také zjištění týkající se informovanosti dětí a mládeže o dopingu, zejména o zdravotních důsledcích jeho uživání, a jsou hledány i nejdůležitější zdroje těchto informací. V některých uváděných studiích jsou patrné snahy komparovat zjištěná data o užívání podpůrných prostředků v našich podmínkách se situací v některých evropských zemích. Slepička, Slepičková, Pyšný, Ludviková (1998) či Slepička, Pyšný (2000) se zabývají i otázkami užívání podpůrných prostředků v rekreačním sportu a upozorňují na možnost prevence a tvorby preventivních programů, $\mathrm{z}$ nichž některé se snaží v rámci uvedených studií i ověřovat v praxi.

Ješke, Nekola, Chlumský (2002) přinášejí statistická data získaná z výsledků dopingových kontrol, která mohou ilustrovat tento problém. Zjistili, že $2 \%$ provedených testů na uživání dopingových látek v různých sportech bylo pozitivních. Tato studie, i když se týká dospělých výkonově orientovaných sportovcủ, je významná i v kontextu problematiky dopingu u sportující mládeže, zejména proto, že situace ve vrcholovém sportu má svůj odraz i v mládežnickém sportu. Úspěšní vrcholoví sportovci se stávají vzorem pro sportující mládež, a podporují tak tendence napodobit i cesty, které vedly k jejich úspěchu. To se může projevovat především v situacích, kdy požadavky na úspěch přicházející z nejbližšího sociálního okolí nelze naplnit běžnými tréninkovými prostředky.

Situaci v rekreačním sportu mapuje např. studie Pyšného (2005) zaměřená na mládež, zejména chlapce navštěvující fitcentra. Zjistil silnou tendenci užívat podpůrné prostředky urychlující nárůst svalové hmoty $\mathrm{v}$ rámci „body buildingu”. Za hlavní důvody uživání těchto prostředků se uvádí sociální prostředí fitcenter $\mathrm{s}$ možnou nabídkou podpůrných prostředků a tolerance $\mathrm{k}$ jejich užívání ze strany dalších, věkově podobných návštěvníků. Významnou roli hrála i potřeba uznání, pozitivní odezvy od vrstevníků v kombinaci s pocitem tělesné nedostatečnosti.

Závažnost problematiky dopingu se projevila i v celoevropském kontextu koncipováním Evropské antidopingové konvence, která stimulovala výzkum dopingu ve sportu dětí a mládeže v mezinárodním kontextu. Vznikla řada studií zaměřených na analýzu tohoto jevu z různých hledisek. Např́klad Yesalis a Bahrke (2000) provedli metaanalýzu mezinárodních studií zaměřených na tuto oblast a uvádějí, že 3 až $12 \%$ dospívajících chlapců a 1 až $2 \%$ dospívajících dívek příležitostně užívají zakázané dopingové prostředky zlepšující výkonnost. Kindlundh et al. (1998) zkoumající švédskou mládežnickou populaci uvádí, že 2,7 \% chlapců a 0,4 \% děvčat někdy užilo dopingové prostředky. Ještě větší procento uvádělo znalost, jakým způsobem lze tyto prostředky opatřit, i když je zatím neužívalo. K obdobným výsledkům dospěli Lucidi a kol. (2008) při zkoumání tohoto problému v Itálii či Pedersen a Wichstrom (2001) v Norsku.

Vedle uvedených studií, které byly zaměřeny na užívání dopingu, se jiní autoři zaměřili na výzkum obeznámenosti mládeže s problematikou dopingu a jejich postojů k jeho užívání. Sas-Nowosielski (2006) zjistila, 
že nadpoloviční většina participantů její studie neměla ani elementární informace o účincích dopingových prostředků, nicméně $10 \%$ chlapců a $2 \%$ dívek připustilo užívání dopingových prostředků. K obdobným výsledkům došel i Johnson et al. (1989) ve studii realizované na amerických adolescentech, kdy 11 \% z nich přiznalo užívání anabolických steroidů.

Uvedené studie v mezinárodním kontextu ilustrují závažnost problematiky rizikového chování sportující mládeže v oblasti užívání různých dopingových prostředků. Proto se mnohé studie zabývaly i otázkami motivace takového chování sportující mládeže. Například Kindlund a kol. (1999) uvádí jako jeden z nejsilnějších motivů pro adolescenty potřebu zlepšit tělesný vzhled a zvýšit sportovní výkonnost. Kanayama, Hudson \& Pope (2008) dosaženými výsledky své studie potvrzují výskyt uživatelů podpůrných prostředků i v rekreačním sportu, kdy hlavním motivem bývá potřeba zlepšit tělesný vzhled tak, aby odpovídal dobovým (módním) požadavkům. Autoři rovněž zmiňují škodlivé účinky užívání dopingu v období dospívání, kdy se v pozdějších letech objevují oběhové, neurologické i psychické obtíže. K obdobným závěrům došla citovaná studie Sas-Nowosielské prezentující jako nejdůležitější motivy užívání „změnit své tělo”, zvětšit svalový objem, změnit body mass index, zvětšit svalovou sílu. Přestože většinu respondentů trápily vedlejší účinky jako akné, ztráta vlasů či deprese, pokračovali v užívání dopingu, zejména anabolických steroidů, paradoxně kvůli zlepšení svého tělesného vzhledu.

Komparativní studie 11 evropských zemí (DeKnop a kol., 1996) dochází k závěru, že sport včetně sportu dětí a mládeže stále ve větší míře zdůrazňuje soutěživost a výsledky, přičemž vítězství má narůstající sociální a ekonomickou významnost. Tyto skutečnosti naznačují, že ve výkonnostně orientovaném sportu je tendence porušovat normy a s tím související tendence užívat dopingové prostředky pro dosažení vítězství se stává stále častějším jevem pronikajícím do sportu dětí a mládeže. K obdobným závěrům dochází i studie Ehrborg \& Rosen (2009) přicházející s názorem, že hlavním motivem pro užívání dopingu je zlepšení tělesných funkcí nezbytných pro výkon v souladu s psychologickým tlakem na dosažení úspěchu a jeho ekonomickým oceněním. Důležitou roli při tom hraje i přístup „vítězství za každou cenu“ často reprezentovaný nejbližším sociálním okolím, a to zejména ve spojení s motivační orientací na výkon a úspěch u samotných mladých sportovců (Petroczi, 2007). Lze uvést zjištění autorů Lentillon-Kaestner \& Carstairs (2010), kdy mladí cyklisté účastnící se jejich studie odmítali uživání dopingu na amatérské úrovni, ale věřili, že je akceptovatelné v profesionální cyklistice, a připustili jeho užívání, pokud by jim pomohl v další cyklistické kariéře na profesionální úrovni.

Pozorovatelný je i vliv širšího sociálního prostředí (Kindlundh et al., 1999), zejména tolerance k překračování sociálních norem v kombinaci s tlakem vrstevníků. Ukazuje se, že silový trénink, rodinné problémy a záškoláctví souvisely s pravděpodobností uživání dopingu. Rovněž užívání jiných drog (marihuany, amfetaminů, opiátů) signalizovaly i možné užívání dopingových látek. Autoři zdůrazňují, že uživání dopingu zahrnuje více než jen snahu o zlepšení tělesné výkonnosti, ale má souvislost i s konzumací alkoholu, kuřáctvím a užíváním psychotropních látek. V našem prostředí potvrdila tyto souvislosti i studie Slepičky a Slepičkové (1996, 1997). Pedersen, Wichstrom a Blekesaune (2001) zjistili, že adolescenti užívající doping inklinují k projevům násilí a jsou mnohem častěji členy skupin orientovaných na projevy násilí.

Pokud si povšimneme psychologických faktorů ovlivňujících užívání dopingu, lze uvést řadu studií, které se tímto tématem zabývají (Kindlundh et al., 2001; Laure, Bissinger, 2007; Zelli, Malia, \& Lucidi, 2010). Jsou uváděny takové faktory jako výsledky školní docházky, vnímaný status, sebejistota, nízké sebeocenění, rysová úzkost, kvalita vnitřních norem a hodnot. Užívání dopingu bylo spojeno zejména s nízkým sebehodnocením, depresemi (včetně tendencí k sebevraždám) a velmi malými znalostmi o zdravotních důsledcích užívání. Kromě toho hrála roli intenzivní účast na sportovních aktivitách, kde byla zdůrazňována svalová síla, váha a tvar těla, spojená s pozitivním rodičovským postojem $\mathrm{k}$ těmto charakteristikám.

Z výsledků uváděných studií je patrné, že vliv na výskyt rizikového chování, za které je možné užívání a dopingových prostředků sportující mládeží považovat, má především sociální prostř̌edí. Zejména se jedná o širší společenské prostředí s orientací na výkon a jeho ekonomické zhodnocení vyplývající z komercionalizace sportu, ale i o prostředí mikrosociální, at jde o rodiče, trenéry či vrstevníky, kteří tyto požadavky přenášejí na sportující jedince, a tím zvyšují jejich psychickou zátěž. K prohloubení problému ještě přispívá malá informovanost př́padných uživatelů o dlouhodobých účincích užívání a mnohdy značná tolerance k problematice uživání různých drog v celospolečenském měřítku. 


\section{Projevy násilí sportujících dětí jako rizikové chování}

Násilí a agrese projevované $\mathrm{v}$ rámci sportu dětí a mládeže lze rovněž přiřadit k rizikovým formám chování často se vyskytujícím zejména $\mathrm{v}$ těch sportovních odvětvích, která umožňují prímý fyzický kontakt. Jde zejména o sportovní hry, jejichž popularita mezi mládeží je dlouhodobě na vysoké úrovni. Proto budeme věnovat pozornost zejména těmto sportovním aktivitám, kde se projevuje sociálně psychologická podmíněnost uvedených jevů v nejširší míře.

I když tato stat' není zaměřena na objasnění teoretických koncepcí násilí a agrese, je možné konstatovat, že teoretické prŕístupy k problematice násilí lze shrnout pod dva základní př́ístupy. Na jedné straně se uvažuje o vnitřních faktorech např́klad ve formě nahromaděné energie (Lorenz, 1966) nebo obecného drivu (Bandura, 1973). V psychologii sportu je často uváděna jako př́íčina uvedených jevů frustrace (Slepička, Hošek, Hátlová, 2009) ve spojení s principem katarze, přinášející násilníkovi určitý stupeň uvolnění, uspokojení. Důležitou roli zde hraje i dynamika, kontrola emocí spolu s hedonistickým principem prožívání (Nevin, 1973). Vedle těchto spíše vnitřních determinant projevů násilí a agrese se stále častěji věnuje pozornost vnějším sociálním determinantám, které souvisejí s učením agresivních vzorců chování pod vlivem modelů obdobného chování jak ve společnosti, tak ve sportu, s vlivem sdělovacích prostředků nebo se sociálním zázemím projevů násilí (Dunning, 1982; Matějček, Bubleová, 1996).

Se sportem dětí a mládeže byla spojena i myšlenka, že integrace do „organizovaného sociálního klimatu“ sportu vytvárí předpoklady pro redukci agrese a násilí. Vycházelo se při tom z předpokladu o preventivním účinku sportu plynoucího z faktu, že integrovaná sportovní skupina má vytvořené kontrolní mechanismy, které spoluurčují chování jedince, aby respektoval dané skupinové normy. Vedle toho se uvažovalo o pozitivním vlivu vzájemných vazeb členů skupiny sdílejících stejné cíle, a mnohdy i obdobné prožitky. V uvedených souvislostech je zajímavá studie Vilhjamsona Thorlinsona (1992), která poukázala na rozdíl mezi rekreačním a organizovaným klubovým sportem, kdy se u klubového sportu více projevovaly prvky skupinového chování pod vlivem skupinových norem.

Výzkumné studie zaměřené na problematiku násilí a agrese (Slepička, Slepičková, 1995, 1996; Nuwer, 2000; Lemieux, McKelvie, Stout, 2002; Fields, Collins, Comstock, 2010) ukazují na nutnost odlišit i ve sportu dětí a mládeže pojem „žádoucí agresivita“, která je často chápaná jako bojovnost, průbojnost a určitá míra tolerované tvrdosti, plynoucí z podstaty provozovaných kontaktních sportů. V těchto př́padech je agresivní chování př́imou podstatou některých sportů (úpolové sporty) nebo nezbytnou součástí mnoha dalších sportů (sportovní hry), a je proto nezbytné rozlišovat mezi agresí v rámci pravidel, kterou lze považovat za žádoucí, a nežádoucí agresivitou a násilím jdoucími nad rámec pravidel. Cílem nežádoucí agrese je získat nedovolenou výhodu, často způsobem, který ohrožuje zdraví a někdy i život soupeře. Lze pozorovat i projevy agrese, jejichž prvotním cílem je fyzicky poškodit soupeře, zranit ho, vyřadit ze hry. V těchto případech nabývá agrese podoby „kvazikriminálního násilí“ překračujícího hranice oficiálních pravidel daného sportu, mnohdy i zákony a neformální hráčské a divácké normy, a je neakceptovatelné (Smith, 1983, Slepička a kol., 2010). Do žádoucí agresivity ve sportovních hrách podle Gerische (1992) či Pappase a kol. (2004) patří tvrdá, ale fair hra tělem, energické napadání ve snaze získat míč, rozhodnost a průbojnost v zakončování akcí, snaha nepřipustit soupeře k akci. Do nežádoucí pak zařazují brutální fauly směřující k „likvidaci“ soupeře.

Je patrné, že pohybové aktivity mohou na jedné straně redukovat projevy násilí vytvořením norem, pravidel a tlaku na jejich dodržování, na straně druhé se mohou sportující děti násilí učit. Některé výzkumy potvrzují spíše pozitivní vliv pohybových aktivit. Buhrman (1977) či Thorlindsson (1989) nalezli souvislost mezi negativním vztahem mládeže ke sportu a zvýšenou delikvencí, Norris a kol. (1992) pak zjistili, že pravidelná pohybová aktivita snižuje u mládeže hostilitu. Blancarte \& Azaková (1992) poukazují na socializační potenciál sportu pozitivně ovlivňující násilí u mladistvých redukcí možností vedoucích k narušení vrstevnických vztahů a komunikace.

V souvislosti s úvahami o rizikovosti výskytu násilí a agrese se objevují studie zkoumající frekvenci výskytu násilí v mládežnické populaci v posledních letech. Např́íklad Fitzgerald, Stevens a Hale (2004) uvádí, že v zemích Evropské unie vzrostly mezi lety 1995 a 2000 př́ípady napadení či přepadení mezi mládeží ve věku do 18 let. McAdams (2002) zjistil v rozsáhlé studii, že zaměstnanci amerických škol udávali signifikantní nárůst záměrné agrese mezi školní mládeží v průběhu posledních deseti let. Př́ičinami tohoto trendu se zabývali např́klad Ferguson a kol. (2009), kteří zjistili, že násilné chování studovaných dětí ve věku 10-14 let nejvíce predikovala přítomnost delikventních vrstevníků, antisociální osobnostní rysy, deprese a zanedbávání a zneužívání dětí. Fraser (1996) ve svém ekologickém přístupu předpokládá, že agresivní chování je důsledkem 
interakce dítěte se sociálními systémy, ve kterých probíhá jeho vývoj.

V oblasti sportu se obdobnými problémy zabývali mimo jiné Pilz (1993), Slepička (1995), Conroy a kol. (2001), Loughead a Leith (2001), Collins, Fields a Comstock (2008). V závěrech těchto prací je možné nalézt celou škálu názorů na projevy násilí sportující mládeží. Často se vyskytuje tvrzení, že mezi sportující mládeží mají větší tendenci $\mathrm{k}$ hrubosti a násilí jedinci, kteří nestačí výkonnostním požadavkům na ně kladeným. Volba těchto prostředků je vedena snahou vyhnout se negativnímu psychickému tlaku, který je na ně vyvíjen v př́ípadě neúspěchu. Ukázalo se rovněž, že projevy násilí jsou vnímány jako legitimnější v př́ípadě, že agrese poskytovala vyšší výhodu a byla malá pravděpodobnost potrestání. V těchto případech hraje rozhodující roli sociální mikroklima, kdy zejména rodiče a trenéři tolerují projevy agrese a násilí jako jednu z cest, jak dosáhnout úspěchu. Přitom se rodiče i trenéři se rovněž dostávají pod tlak zejména pod vlivem komercionalizace sportu, která chápe výkon jako rozhodující cílovou kategorii již u mládeže. Bylo také poukázáno na význam zvyšující se role výkonnostní úrovně, kdy se na mladých hokejistech prokázalo, že se zvyšující úrovní hry rostl výskyt hostilních, násilných zákroků. Starší děti také nepovolené zákroky více schvalovaly a ve větší míře považovaly agresi za běžnou součást sportu, které se nelze vyhnout. Závažným faktorem při výskytu agrese a násilí je imitační učení. Uvedené studie přinášejí i zjištění o vlivu nápodoby chování úspěšných sportovců, kdy jsou napodobovány i projevy násilí. Přitom agresivní, násilné chování modelu působí jak ve smyslu imitačního učení, tak aktivizuje agresivní reakce, které imitátor již znal. Jde tedy o to, že potlačené, utlumené agresivní, násilné chování bývá opětovně aktivováno působením sportovního vzoru, který toto chování veřejně a bez sankce předvádí.

V uvedených souvislostech se objevuje otázka, nakolik se toto ze společenského hlediska rizikové chování přenáší i mimo oblast sportu. Je možné nalézt řadu výzkumných studií tematicky zaměřených na možný přenos agrese a násilí do běžného života sportující mládeže. Pro ilustraci uvádíme výzkum realizovaný Forbesem a kol. (2006), kteří zjistili, že studenti věnující se na střední škole kontaktním sportům (např́klad zápasu či americkému fotbalu) udávali ve srovnání se svými vrstevníky častější výskyt agresivního chování vůči svému nejbližšímu sociálnímu okolí. Huang a kol. (1999) v rámci laboratorní studie zjistili, že středoškolští studenti, kteří se účastnili kontaktních sportů (jako například amerického fotbalu či basketbalu) vykazovali vyšší agresivní reakce než jejich vrstevníci účastnící se nekontaktních sportů (např. atletiky). Endersen a Olweus (2005) v longitudinální studii zjistili, že účast v silových sportech (powerlifting, kulturistika, box, zápas, bojové sporty) pozitivně souvisela u chlapců ve věku 11-13 let s vyšším výskytem agresivního a anti-sociálního chování. Autoři pak zvažují, nakolik je tato situace ovlivněna specifickými podmínkami sportovního prostředí a jakou roli hrají osobnostní dispozice. Konstatují však v souladu s výsledky studie, že značný podíl na tom má prímo účast $\mathrm{v}$ daném sportu. Roli podle nich hraje především zprostředkování norem, postojů a ideálů, které převažují v těchto pohybových aktivitách. Na roli norem a postojů pokazují i Lakes a Hoyt (2004), kteří zjistili, že děti účastnící se bojového sportu taekwondo projevovaly ve srovnání s dětmi navštěvujícími pouze hodiny školního tělocviku vyšší schopnost seberegulace v kognitivní a emoční oblasti a také vyšší úroveň prosociálního chování. Na základě uvedených skutečností lze konstatovat, že agresivní chování projevované v rámci různých pohybových aktivit (např. bojová umění), kde je zdůrazňován hodnotový, prožitkový a výchovný prvek, může být postupně utlumováno. Naopak tam, kde je akcentována soutěžní stránka, souvisí délka provozování aktivit s projevovanými agresivními tendencemi pozitivně, a riziko přenosu do ostatních sfér života sportujících dětí se zvyšuje.

\section{Fair play jako prvek regulující rizikové chování}

Rizikové chování sportující mládeže, jak bylo prezentováno v předchozích částech stati, patří rovněž k formám chování překračujícím hranice sportovních pravidel, a tudíž i přístup shrnutý pod pojem fair play, ale mnohdy i sociální normy platné mimo oblast sportu. Mezi obdobné chování překračující tyto hranice se zařazuje i podvádění a nedodržování stanovaných pravidel v průběhu sportovní činnosti. I na tuto problematiku spojenou s tendencemi překračovat stanovená pravidla ze strany sportující mládeže byla zaměřena řada studií zjišt'ujících zejména př́činy takových reakcí. Pro ilustraci problému je možné uvést studii realizovanou Boixadosem a kol. (2004), kteří zjistili ve studii 472 španělských fotbalistů ve věku 10-14 let, že pokud vnímali motivační klima v rámci tréninkové skupiny jako zaměřené na činnost samotnou (task climate), tak udávali také větší spokojenost s tréninkem, cítili se kompetentnější a udávali negativní postoje k nečisté hře mimo rámec pravidel. Naopak když vnímali motivační klima jako zaměřené na soutěž s druhými a málo na činnost samotnou, tak udávali pozitivnější postoje k agresivní hře mimo rámec pravidel. K obdobným výsledkům došli Miller a kol. (2004), 
kteř́ zjistili ve studii 705 norských fotbalistů a fotbalistek ve věku 15-16 let, že pokud vnímali motivační klima v týmu jako silně zaměřené na soutěž, tak současné udávali nižší úroveň morálního usuzování - schvalovali používání soutěžních praktik mimo rámec fair play, jako například zastrašování, faulování či podvádění.

Na možné souvislosti tolerance k překračování pravidel s narůstajícím věkem sportujících dětí a rozvojem jejich sportovní kariery poukázaly studie Pilze (1993) či Slepičky (1994). U mladých hráčů hokeje a kopané byla zjištěna s délkou sportovní kariery narůstající tolerance k porušování pravidel, s cílem zvýšit pravděpodobnost úspěchu. U dvanáctiletých hráčů, stojících na začátku své kariery, připustila porušení pravidel pro dosažení úspěchu jen třetina, mezi osmnáctiletými to bylo již $65 \%$. Byla patrná tendence s postupujícím věkem posuzovat nutnost respektovat pravidla zejména ve vazbě na možnosti dosažení cíle. Ukázalo se rovněž, že mezi osmnáctiletými sportovci jich 10 \% uvedlo, že agrese „ohleduplně provedená“ je součástí fair play hry. Zajímavé bylo i porovnání těchto na výkon orientovaných sportujících dětí s jejich vrstevníky nesportujícími anebo sportujícími jen rekreačně. Výkonově sportující jedinci vykazovali vyšší tendenci k účelovému překračování stanovených sociálních norem, mezi něž lze zařadit i sportovní pravidla. Zajímavou studií byl výzkum provedený na 279 fotbalistech ve věku 12-14 let pocházejících z různých evropských zemí. Ten ukázal, že hráči, kteří vnímali motivační klima v rámci svého klubu jako zaměřené převážně na soutěž, udávali vyšší výskyt amorálního chování a spíše odmítali zásady fair play (Ommundsen, Roberts, Lemyre, Treasure, 2003). Potvrdila se tak významnost orientace na výkon a jeho ocenění pro tolerování překračování pravidel, podvádění jako prostředku k dosažení cíle, kterým je sportovní úspěch.

$\mathrm{Na}$ důležitost hodnotové orientace ve vztahu k fair play chování ve sportu dětí a mládeže poukazují např́íklad Lee a kol. (2008), kteří zjistili ve své rozsáhlé studii zaměřené na mladé sportující jedince ve věku 12-15 let, že pokud zastávali hodnoty zdůrazňující sportovního ducha, fair play a pomoc druhým, tak s větší pravděpodobností odmítali negativní chování, jako např́klad podvádění či agresivní chování vůči protivníkům. Naopak pokud udávali výraznou orientaci na soutěž a získání sociálního statusu prostřednictvím sportu, tak $\mathrm{s}$ větší pravděpodobností takovéto negativní chování schvalovali.

Pro vztah k sociálním normám obecně a v případě sportu $\mathrm{k}$ sportovním pravidlům je velmi důležitý vliv sociálního mikroklimatu (rodiče, učitelé, trenéři). Ti zprostředkovávají přenos těchto norem na své svěřence a jsou i reprezentanty požadavků nejbližšího sociálního prostředí pro sportující děti a mládež. Ntoumanis a Standage (2009) zjistili na vzorku více než tří set respondentů, že pokud trenéři podporovali jejich autonomii a dávali jim prostor činit vlastní rozhodnutí, tak sportovci udávali vyšší identifikaci se sportovními ideály, zásadami fair play a prosociálními postoji, než když se trenéři projevovali jako kontrolující, jednoznačně určující výkonnostní cíle.

\section{ZÁVĚRY}

Na základě poznatků představených studií lze konstatovat, že chování, které je v souladu s principy shrnutými pod pojem fair play, se dostává pod tlak sociálního prostředí i ve sportu dětí a mládeže. Společnost vytváří určitý systém hodnot, sociálních norem, regulujících její život. Společenská praxe však tomuto systému hodnot a norem mnohdy neodpovídá. Nezbytná adaptace jedince na dané sociální prostředí včetně specifického prostředí sportu vede $\mathrm{k}$ tomu, že obecně proklamované hodnoty, normy nedokáže plně akceptovat. Jak z uvedeného vyplývá, stále více je i ve sportu dětí a mládeže oceňován především úspěch, při jehož dosažení je tolerováno i překračování obecně proklamovaného fair play př́istupu. Přestože se ve sportu dětí a mládeže obecně uznává nutnost všestranného rozvoje jejich osobnosti, většinou se rozvíjí tělesné funkce, stimuluje se odolnost, tvrdost k sobě i druhým, a ostatní je pokládáno za nadbytečné. Malá stimulace hodnotových, normotvorných aspektů sportu vede $\mathrm{k}$ výskytu takových jevů jako je užívání dopingu, násilí a podvádění i v mládežnickém sportu. Chování z toho vyplývající je možno označit za rizikové, zejména z hlediska rozvoje osobnosti mladých lidí, a přenos tohoto chování do jejich dalšího života je, jak ukazují výsledky studií, velmi reálný.

\section{LITERATURA}

Bandura, A. (1973). Agression: A social learning analysis. Englewood Cliffs. New Jersey: Prentice-Hall. Blancarte, S., \& Azeka, B.J. (1992). A pluralistic approach to gang prevention: The long beach model. Journal of $P$. E., recreation and dance, 63, 4, 31-33.

Boixadós a kol. (2004). Relationships Among Motivational Climate, Satisfaction, Perceived Ability, and Fair Play Attitudes in Young Soccer Players. Journal of applied sport psychology, 16, 301-317. 
Buhrman, H. G. (1977). Athletic and deviance. Review of sport and Leisure, 2, 17-35.

Collins, C.L., Fields, S.K., \& Comstock, R.D. (2008). When the rules of the game are broken: what proportion of high school sports-related injuries are related to illegal activity?. Injury Prevention, 14, 34-38.

Conroy, D.E., Silva, J.M., Newcomer, R., Walker, B., \& Johnson, M. (2001). Personal and Participatory Socializers of the Perceived Legitimacy of Aggressive Behavior in Sport. Aggressive Behavior, 27, 405-418.

DeKnop P. (1996). European Trends in Youth Sport: A Report from 11 European Countries. European Journal of Physical Education, 1, 36-45.

Dunning, E., a kol. (1982). The social roots of footbal hooligan violence. Leisure studies, 1, 14-28.

Ehrborg, C., \& Rosen, T. (2009). The psychology behind doping in sport. Growth Hormone and IGF Research, $19,285-287$

Endersen, I.M., \& Olweus, D. (2005). Participation in power sports and antisocial involvement in preadolescent and adolescent boys. Journal of child psychology and psychiatry, 46, 5, 468-478.

Ferguson, C.J., San Miguel, C., \& Hartley, R.D. (2009). A Multivariate Analysis of Youth Violence and Aggression: The Influence of Family, Peers, Depression, and Media Violence. Journal of pediatrics, 155, 6, 904-908.

Fields, S.K., Collins, C.L., \& Comstock, R.D. (2010). Violence in youth sports: hazing, brawling and foul play. British journal of sport medicine, 44, 32-37.

Fitzgerald, M., Stevens, A., \& Hale, C. (2004). A Review of the knowledge on juvenile violence: trends, policies and responses in the EU member states. European Crime Prevention Network.

Fraser, M.W. (1996). Aggressive behavior in childhood and early adolescence: an ecological-developmental perspective on youth violence. Social Work, 41,4, 347-361.

Forbes, G.B. (2006). Dating Aggression, Sexual Coercion, and Aggression-Supporting Attitudes Among College Men as a Function of Participation in Aggressive High School Sports. Violence against women, 12, 441-455.

Gerisch, G. (1992). Positive Aggression - Einstellung und Verhalten im Wettkampf. BDFL Journal, 4, 21-24.

Huang, D.B. a kol. (1999). Laboratory measurement of aggression in high school age athletes. Psychological reports, $85,1251-1262$.

Lakes, K.D., \& Hoyt, W.T. (2004). Promoting self-regulation through school-based martial arts training. Applied Developmental Psychology, 25, 283-302.

Jeschke, J., Nekola, J., \& Chlumský, J. (2002). Doping v číslech a komentáŕích. Medicina Sportiva Bohemica et Slovaca, 11, 1, 1-20.

Johnson. M. D., Jay, M. S., Shoup, B., \& Riekert, V. 1. (1989). Anabolic steroid use by male Adolescents. Pediatrics, 3, 91-92.

Kanayama, G., Hudson, J.I., \& Pope, H.G. (2008). Long-term psychiatric and medical consequences of anabolic-androgenic steroid abuse: A looming public health concern? Drug and Alcohol Dependence, 98, 1-12. Kabiček, P. (2005). Zneužívání anabolických steroidů u dospívajících . Vox Pediatriae, 3,5, 14-16.

Kindlundh, A.M.S., Isacson, D.G., Berglund, L., \& Nyberg, F. (1998). Doping among high school students in Uppsala, Sweden. Scandinavian Journal of Public Health, 26,1, 71-74.

Kindlundh, A.M.S., Isacson, D.G., Berglund, L., \& Nyberg, F. (1999). Factors associated with adolescent use of doping agents. Addiction, 94,4, 543-553.

Kindlundh, A.M.S., Hagekull, B., Isacson, D.G.L., \& Nyberg, F. (2001). Adolescent use of anabolic-androgenic steroids and relations to self-reports of social, personality and health aspects. European Journal of Public Health, 11,3, 322-328.

Laure, P. \& Binsinger, C. (2007). Doping prevalence among preadolescent athletes: a 4-year follow-up. British Journal of sports medicine, 41, 660-663.

Lee, M.J., Whitehead, J., Ntoumanis, N., \& Hatzigeorgiadis, A. (2008). Relationships Among Values, Achievement Orientations, and Attitudes in Youth Sport. Journal of sport and exercise psychology, 30, 588-610. Lentillon-Kaestner, V., \& Carstairs, C. (2010). Doping use among young elite cyclists: a qualitative psychosociological approach. Scandinavian Journal of Medicine and Science in Sports, 20, 336-345.

Lemieux, P., McKelvie, S.J., \& Stout, D. (2002). Self-reported Hostile Aggression in Contact Athletes, No Contact Athletes and Non-athletes. Athletic Insight, 4,3, 42-56.

Lorenz, K. (1966). On aggression. New York: Harcourt, Brace and World.

Loughead, T.M., \& Leith, L.M. (2001). Hockey coaches' and players' perceptions of aggression and the aggressive behavior of players. Journal of Sport Behavior, 24, 4, 394-407. 
Lucidi, F. et al. (2008). The social-cognitive mechanismus regulating adolescents' use of doping substances. Journal of Sport Sciences, 26, 5, 447-456.

Matějček, Z., \& Bubleová, V. (1996). Pozdní následky psychické deprivace a subdeprivace. Československá psychologie, 2, 81-93.

McAdams, C. R. (2002). Trends in the Occurrence of Reactive and Proactive Aggression Among Children and Adolescents: Implications for Preparation and Practice in Child and Youth Care. Child and youth care forum, 31,2, 89-109.

Miller, B.W., Roberts, G.C., \& Ommundsen, Y. (2004). Effect of perceived motivational climate on moral functioning, team moral atmosphere perceptions, and the legitimacy of intentionally injurious acts among competitive youth football players. Psychology of sport and exercise, 6, 461-477.

Nevin, J.A. (1973). Stimulus control. In Nevin, J.A. (Ed.). The study of behavior: Learning, motivation, emotion and instinct. Glenview, Il. : Scott, Foresman.

Norris, R., a kol. (1992). The effect of physical activity and exercise training on psychological stress and wellbeing in adolescent population. Journal of psychosomatic research, 36, 1, 55-65.

Ntoumanis, N., \& Standage, S. (2009). Morality in Sport: A self-determination theory perspective. Journal of applied sport psychology, 21, 4, 365-380.

Nuwer, H. (2000). High school hazing. When rites become wrong. New York: F. Watts.

Ommundsen, Y., Roberts, G.C., Lemyre, P.N., \& Treasure, D. (2003). Perceived motivational climate in male youth soccer: relations to social-moral functioning, sportspersonship and team norm perceptions. Psychology of sport and exercise, 4, 397-413.

Pappas, N.T., McKenry, P.C., \& Catlett, B. S. (2004). Athlete Aggression on the Rink and off the Ice. Men and Masculinities, 6, 3, 291-312.

Pedersen, W., \& Wichstrom, L. (2001). Adolescents, Doping Agents, and Drug Use: A Community Study. Journal of Drug Issues, 31, 2, 517-542.

Pedersen, W., Wichstrom, L., \& Blekesaune, M. (2001). Violent behaviors, violent victimization, and doping agents. Journal of Interpersonal Violence, 16, 8, 808-832.

Petroczi, A. (2007). Attitudes and doping: a structural equation analysis of the relationship between athletes attitudes, sport orientation and doping behaviour. Substance abuse treatment, prevention, and policy, 2, 34 .

Pilz, G. (1993). Social factors influencing sport and violence. Lisbon: Proceedings of 8th congress of sport psychology.

Pyšný, L. (1999). Doping, zdraví, výkon. Karolinum: Praha.

Pyšný, L. (2005). Motivace a demotivace př́ijmu anabolických steroidů. Vox Pediatriae, 3,5, 20.

Sas-Nowosielski, K. (2006). The abuse of anabolic-androgenic steroids by polish school-aged adolescents. Biology of Sport, 23, 3, 225-235.

Slepička, P., \& Pyšný, L. (2000). Problematika dopingu a možnosti antidopingové prevence. Karolinum: Praha. Slepička, P., Hošek, V., \& Hátlová, B. (1999). Psychologie sportu. Praha: Karolinum.

Slepička, P., Slepičková, I., Pyšný, L., \& Ludvíková, M. (1998). Sociální aspekty dopingu. Česká kinantropologie, 2, 1, 21-40.

Slepička, P., \& Slepičková, I. (1997). Antidoping prevention for children and youth. Acta Facultatis Educationis Physicae Universitatis Comenianae, 127-137.

Slepička, P., \& Slepičková, I. (1996). Social Aspects of Doping and Antidoping Prevention Possibilities in Children and Youth. Acta Universitatis Carolinae Kinanthropologica, 32, 2, 23-34.

Slepička, P. (1994). Fair play a současnost. Sport report, 33, 9, 94-97.

Slepičková, I., \& Slepička, P. (1996). Problems of aggression and violence with sporting and non sporting youth. In Muthian, H., Mohan, J. (Eds.) Perspectives of Sports Science. Friends publications: New Delhi.

Slepičková, I., \& Slepička, P. (1995). Problems of aggression and violence with sporting and non sporting youth. Acta Universitatis Carolinae Kinatropologica, 31,2,29-37.

Smith, M.D. (1983). Violence and sport. Toronto: Butterworths.

Thorlindson, T. (1989). Sport participation, smoking and drug and alcohol use among Icelandic youth. Sociology of Sport, 6, 183-195.

Vilhjalmson, R., \& Thorlindson, T. (1992). The integrative and physiological effects of sport participation: A study of adolescents. The sociological quarterly, 33,4, 637-647. 
Yesalis, C.E., \& Bahrke, M.S. (2000). Doping among adolescent athletes. Clinical Endocrinology and Metabolism, 14, 1, 25-35.

Zelli, A., Mallia, L., \& Lucidi, F. (2010). The contribution of interpersonal appraisals to a social-cognitive analysis of adolescents' doping use. Psychology of Sport and Exercise, 11, 304-311. 